\title{
DEMAZHABIZATION OF ISLAM, DIVINITY ECONOMY AND NARRATIVES OF CONFLICT OF THE TABLIGHI FOLLOWERS IN SAMARINDA EAST KALIMANTAN
}

\author{
Saipul Hamdi \\ Samarinda State Polytechnic of Ugriculture
}

\begin{abstract}
Tablighi Jamaat is one of the world's largest and most successful transnational Islamic movements with established branches built on the business of dakwa (proselytization) in approximately 180 countries. Tablighis strong commitment to a style of dakwa based on their reformist attitude and flexible practice of mazhab (schools of thought) through a process of 'demazhabizasi' (demahzhabization), has attracted interest from a range of people. Tablighi guarantees the freedom for its members to embrace their choice of mazhab, and prefers its proselytizers to follow the mazhab of the communities in which they preach in order to avoid religious debates. This article aims to understand the concept of 'demazhabisasi' that has developed in Tablihgi and the ways in which Tablighi members work to overcome and prevent conflict due to the different understandings of each mazhab. The material sacrifices Tablighi proselytizers make together with their reliance on and submission to God for their economy, has led this research to examine the concept of a 'divine economy' that has developed in Tablighi communities. Yet, behind Tablighi's apparent success, conflict has emerged internally among Tablighi members, as well as externally among locals in the communities in which Tablighi proselytizers work. This research uses an ethnographic approach to explore narratives of conflict that have emerged as a result of Tablighi proselytizing practices in Samarinda, East Kalimantan.
\end{abstract}

Keywords: The Tablighi, demazhabization, economy of divinity and narrative conflict

\section{INTRODUCTION}

The transnational political-dakwa movement led by the Tablighi follower group, Hizb ut-Tahrir, Wahabis, Ahmadis and the Muslim Brotherhood has been growing in the last four decades and had a strong influence ideologically in many countries. Among the transnational movements, the Tablighi group has been the most 'successful' for a while as it is capable of existing and being consistent with their militant dakwa movement, 'salafi' and globalized. Despite having a clear organizational structure like other community organizations, 
institutions or political parties, the Tablighi movement is very well organized, disciplined and orderly, using consensus to make decisions (Abdurrahman Ahmad As-Syirbuni, 2010). The Tablighi has branches in 180 countries spread across the continents with approximately 80 million members. The Tablighi's success as a global dakwa movement is controversial in the community. The Tablighi has also been affected by the political movement of global terrorism in which it, by some Western researchers, is seen as sponsor of jihadists in the bombing cases in Britain, United States and France (Muhammad Amira Rana, 2009). Even Fred Burton and Scott Stewart claimed that The Tablighi had a secret latent network with terrorist groups in Pakistan (Joshua W. Hedges, 2008). This claim requires further proof because the Tablighi's culture and discourse are different from country to country so it should not be generalized. During my field study in Samarinda and Balikpapan, for example, I never heard of a member of The Tablighi discussing political issues, violence or racism campaign against the West that became the parameters to decide whether or not it was part of a terrorist group.

The headquarters (markas) is a center for the Tablighi activities, in which all members gather to attend the bayan religious lecture once a week and hold a meeting to discuss the dakwa agenda and evaluate its opportunities and challenges. The place used as the headquarters is usually a mosque which is designed not only for worship but also for the Tablighi dakwa center. The mosque plays an important role in the practice of The Tablighi religious rituals; without it, the Tablighi would be unable to perform preaching activities (Fikri Rivai, 2010). Their mission is to strengthen the faith and deeds of Muslims through prayers in mosques. The mosque grandeur is not important to the Tablighi, but enlivening the mosque for religion. The Tablighi mosque also serves as a pesantren (Islamic boarding school) for Quranic studies ranging from children to teenagers. The Tahfiz Pesantren is one of the Tablighi pesantren education identity. The latest trend among The Tablighi families in Samarinda is to send their children to the Tahfiz pesantren with leaving formal education.

Tablighi is growing rapidly in Southeast Asia, including Indonesia, Singapore, Thailand, Brunei, and Malaysia. The Tablighi's presence in Southeast Asia has given a new color in the pattern of local Asian religious communities (Faris A. Noor, 2012). The Tablighi movement has become an 'alternative' dakwa movement to bring new interpretations and patterns of more egalitarian and non-hierarchical dakwa between clerics with worshipers (Ariesta, 2009). Tablighi provides more space for the community to develop the potential of their teachings, so that everyone is not only a loyal listener, but also plays 
an active role as a preacher inside and outside the Tablighi. This is what distinguishes the Tablighi to other community organizations, where only clerics are entitled to hold the authority to teach in their communities. Seeing new patterns and systems, people from the outside of Tablighi claim that the Tablighi preachers are ignorant because they do not know the science of Islam (Abdurrahman Ahmad As-Syirbuni, 2010). The Tablighi group makes a new step in the recruitment of members by putting aside differences in sects and cults of each member. This concept is what the author refers to as 'demazhabization' of Islam, i.e. releasing Islam from the grip of the culture of schools of thought.

This article explores the concept of 'demazhabization' of Islam that developed within the Tablighi and how they accommodate differences of schools of thought internally and how they manage conflicts arising from these differences. The issue of schools of thought has become a global issue because it is positioned as a doctrine or ideology to be followed as a whole and should not be mixed with other schools. Problems arise when a group with a particular school of thought blames the others. They desperately defend their schools as the 'most right'. As a result, friction and conflict cannot be controlled, even it is not uncommon to end up with violence and sectarian war (Saipul Hamdi, 2011). Conflict of schools of thought may turn increasingly sensitive when political and economic interests are involved, especially as it is used as a school of thought adopted by the state to legitimize the rule as in Saudi Arabia and Brunei Darussalam (Tim Ahlul Bait Indonesia, 2012). Demazhabization pattern by the Tablighi in addition to receiving a positive response from the Muslim communities in Indonesia (NU, Muhammadiyah, Persis and NW), it also got a strong criticism from the Wahhabis because it disclaims discourse and theology in their academic culture. This arises because the Tablighi avoid the discourse and debate containing khilafiyah, but prioritize worship and dakwa.

The Tablighi dakwa challenge is not only related to the issue of school of thought, but also in the approach of dakwa they adopt. Some residents feel uncomfortable with their visit, knocking at the door to deliver one or two verses. This, to some people violates the privacy and freedom of religion as prayer is personal responsibility. This approach often results in conflict with local communities. Another issue that arises is related to the Tablighi's responsibility in ensuring economic prosperity of their family because of the need to dakwa. Financial constraints force members of the Tablighi to sell the property in order to meet the needs of preaching, but they continue to remain committed to Allah. For them, Allah is the source and giver of sustenance. The 
concept of not caring about the material and submit all economic problems to Allah brings further questions about the economic concept of 'divinity' built by members of the Tablighi and economic impact on families.

\section{TABLIGHI FOLLOWERS IN SAMARINDA}

Before discussing the description of Tablighi followers in Samarinda, the author will give a brief profile of the city of Samarinda. Samarinda is derived from the word 'equal' and 'low', which means there is no difference in social status in public life in this city both for migrants and natives. The word 'similar' and 'low' then changed the spelling to Samarinda. The city was named by the king of Kutai to maintain the stability and harmony of the whole tribe, language, and religion in this town. The city of Samarinda was a Bugis Wajo village built in order to seek political asylum from the king of Kutai in 1668 as a result of the defeat of the king of Gowa from the Dutch. The king of Kutai initially gave the agricultural land of Karang Mumus with an agreement that Daeng Mangkona and his followers will help the king against the Dutch who began to enter into the kingdom.

Samarinda is the capital of the province of East Kalimantan which is directly bordered by Kutai Kertanegara Regncy. Samarinda has an area of $718.00 \mathrm{~km}$ with an entrance through the Mahakam river. At the end of 2010, Samarinda was divided into 10 sub-districts with the highest population density in East Kalimantan which reached 805.688 followers, 416.975 men and 388.713 women. Samarinda population was dominated by the trans-migrants from Java (29.55\%), Bugis (18.26\%), Banjar (13.94\%), Dayak (9.91), Kutai (9.21), Toraja (1.96), Madura (1.24) and Chinese (1.16). the indigenous majority (Dayak) live in the upstream region inland away from the life of modernity. Only a small proportion lives in cities and take part in the elections of governor or regent / mayor. One of the Dayak figures, Syahari Ja'ang, was elected Mayor of Samarinda in the period of 2010-2015 (BPS, 2014).

Based on data obtained from Samarinda Religious Ministry Office, religions in Samarinda include Islam with 700.234 followers (90.94\%), Protestantism 40.086 followers (5:20\%), Catholicism 17.290 followers (of 2.25\%), Buddha 8.295 followers (1:08\%), and Hindu 1,052 followers (0:14\% ). The relationship between religious groups in Samarinda is quite harmonious, away from the issue of conflict and social violence. Each of these religious communities coexists freely to practice tolerance. The Lempake area that serves as the headquarters of Tablighi followers consists of three centers, namely AlMubarok (Headquarters Tablighi), Catholic Center and Buddhist Center. The three religious groups compete fairly with no friction or sectarian conflict. 
Local governments have an important role in establishing harmony between religions by providing worship facilities proportionately. In 2009, the number of mosques in Samarinda was 810 and the number of churches 71 . The Islamic Center Mosque Samarinda is the largest mosque in East Kalimantan with an area of 43,500 meters.

Religious activities go hand in hand with the development of industry and modernity in Samarinda. Modernity and religion need no conflict, but can go along together and complement each other in public life of Samarinda. Mosques and prayer rooms are never devoid of religious activities, as well as shopping malls and entertainment places. Islam in Samarinda consists of various sects carried by the clerics of Banjar, Javanese, Bugis, Lombok and Madura. The Banjarese domininate the mosques in Samarinda as ta'mir and preachers. One characteristic of Islamic clerics of Banjar is that before the sermon, Habsi traditional music is performed (singing and shalawat accompanied by kasidah music). Islamic organizations from outside the region are also growing rapidly in Samarinda like NU, Muhammadiyah, LDII, Hizb ut-Tahrir Indonesia and the Tablighi. The Tablighi followers in East Kalimantan were brought in by the preachers of Java and Sulawesi in the 1980s. the development of Tablighi doctrine is significant in East Kalimantan, where members are approximately 8000 people from all walks of life ranging from academics, employees, merchants, officials, farmers and thugs.

The Tablighi followers in Samarinda are approximately 1,000 people spread in 20 Mahallas (mosque). The activity centers at the headquarters of Al-Mubarok Mosque, on Lempake Road, Northern Samarinda, where all Ahbab or karkun gather to listen to the bayan every Friday night. After the Bayan, they discuss the activities that will be carried out primarily Khuruj program, then continue with dinner. The headquarters of Al-Mubarok also has Tahfiz Al-Quran boarding school for female students coached by Ustaz Maulana Arif, whereas for male boarding school, it is built in the area Pampang, Tanah Merah approximately $5 \mathrm{~km}$ from the headquarters. In addition, Tahfiz Al-Quran of the Tablighi has also been opened in the residential area of Bukit Pinang under the guidance of Ustaz Nizar. The new headquarters built for the area Samarinda is the Tablighi mosque of Sungai Siring an area of approximately 6 ha. The Tablighi headquarters in the mosque Al-Mubarok will be moved to the mosque in Sungai Siring because of its bigger capacity.

\section{BUILDING A NEW THAREQAT FOR SOCIAL AWARENESS}

Each mazhab in Islam has a specific methodology of interpreting the teachings of Islam. Wahabism is known for their 'salafi', HTI 'for the khilafah' 
Muhammadiyah for 'renewal', Hidayatullah for 'Qur'an' NU for 'Azwaja', Ahmadiyah for 'Mesiah', Shiites for 'imamah' and the Tablighi for 'preaching. The Tablighi founder, Sheikh Ilyas formulated a new methodology known as Thareqat Nabawi. Thareqat Nabawi is a thareqat that emphasizes on preaching exemplified by the Prophet and his companions in the early history of Islam. To revive Thareqat Nabawi, the outlines of the rules of preaching known as 'orderly' should be made so as to regulate the activities of both dakwa and technical concepts that must be followed by the congregation when becoming a member. This 'orderly' rule is a general agreement that must be executed with sincerity, discipline and total submission in order to obtain a perfect result (Abdurrahman Ahmad As-Syirbuni, 2010).

The new methodology of which is constructed by the Tablighi is not widely understood by the public. The thareqat nabawi dakwa method popularized by Sheikh Ilyas has a clear lineage from Prophet Muhammad, Companions and scholars of Sufi. I argue that the dakwa movement the Tablighi is part of 'neoconservative' Sufism, the movement that strives to maintain the old traditions, but at the same time creates new contextual elements. Muhammad Amir called Rana Ilyas Sheikh dakwa movement as reform Sufism (Muhammad Amir Rana, 2009). Many old traditions are preserved until today, for example the Prophet's militancy in preaching and how to position religion as a business area, and they also create new patterns such as Khuruj fi sabilillah which takes 3 days, 40 days or 4 months (Husen Usman Kambayang, 2009; Christopher Deliso, 2007).

The Thareqat Nabawi introduced by Sheikh Ilyas is a combination of four thareqats i.e. Al-Jistiyah, Naqsabandiyah, Qadariyah and As-Sharowardiyah, which was then modified to emphasize on dakwa. Sheikh Ilyas did not agree with the concept of the 'conventional' thareqat, where members just sit doing wirid, tafakkur and heal themselves instead of helping the community. He saw the importance of preaching while practicing the teachings thareqat together in mosques through Khuruj fi sabilillah program. Muslims need to sacrifice for the religion, not just sitting alone while the communities are in a state of weak faith. Da'wah should be sustainable even if only done briefly (Yonginder Sikand, 2007). The slogan used is 'deliver about religion even if only one verse'. This is the reference used by the Tablighi in building their epistemology of dakwa methodology.

In order to maintain continuity in the public dakwa, the Tablighi design a Khuruj fi sabi lillah program. Khuruj is one of the methods of the program of the Tablighi dakwa. Khuruj comes from the Arabic meaning going out, this term is then used in the context of preaching out in the community. Khuruj 
spirit is drawn from the event of Prophet Muhammad's migration to Medina when spreading Islam (Marloes Janson, 2014). All members of the Tablighi are encouraged to do Khuruj in order to establish the character of religiosity. Khuruj can be done for 3 days, 40 days and 4 months with the basic concept that $10 \%$ of the time is used for religion. The $10 \%$ count covers three days in a month, 40 days a year and 4 months for a life time. Khuruj of 3 days is performed at the level of khalaqah in mosques in the village or district level, and 40 days in mosques across the province, while four months is usually in one of the Tablighi centers, namely India, Pakistan and Bangladesh (IPB). If you've been out to one of IPB, the members of the Tablighi is deemed spiritually mature and could be preaching to the distant land.

Khuruj activity is equal to 'solitude' in the concept of Sufism that is alienating oneself from the life of the world and focus on running the worship of Allah. Although the term Khuruj is different from the 'solitude', it essentially has similar nature, alienating the heart and soul away from the worldly life. In the Al-Quran it is told that 'solitude' was done by ashabul kahfi for hundreds of years in the cave, the prophet Moses on the hill of Tursina for 40 days, the prophet Muhammad in the cave hira and the Sufi scholars to the mountains to seek the truth (Muhammad Sholikhin, 2009). The Tablighi do not use the term 'solitude', but instead use Khuruj fi sabilillah where they do not retreat to the cave, but to mosques and still establish communication with the outside community around for the sake of dakwa. During my three days of Khuruj in the mosque Palaran, Samarinda, all members had to pray in congregation at all times and should not be out of the mosque without permission of the amir. We woke up in the middle of the night to perform tahajjud prayer, dawn prayer and to listen to the bayan for 15-30 minutes.

In addition to bayan, the congregation also held a book study on Fadhoilul Amal written by Sheikh Maulana Zakaria essay. The taklim was delivered alternately by reciting certain chapters in the book Fadhoilul Amal. In the late afternoon before sunset some members did jaulah, traveling to homes to perform dakwa. They knocked at the door, introduced themselves and delivered the purpose of preaching. They invited people to evening prayers in congregation to listen to the bayan until evening prayer (Abdurrahman Ahmad AsSyirbuni, 2010). Not all members participate in the jaulah, mostly staying in the mosque doing study groups, remembrance and pray for success of jaulah. Those who did the jaulah divided the role as a dalil, a guide, usually the Tablighi members of the local village, mutakallim, spokesman, and makmur. Before leaving for jaulah, the group prayed in front of the mosque standing in a circle. Each visit took only 3-5 minutes to catch the quantity and 
avoided talking about topics outside religion.

During Khuruj the Tablighi also had a program to meet scholars around the region. Silaturrahmi aims to pay homage to the scholars and build ukhuwah Islamiyah network. When a Khuruj entourage from Sri Lanka in Balikpapan visited Ar-Rahman mosque, I accompanied the group to visit Al-Mujahideen pesantren. The delegation of the Tablighi began to introduce themselves and delivered the preaching mission to leader of the pesantren. What is interesting was that the Tablighi leader and the kyai was of the same AlJistiyah thareqat. Both of them could match the deeds of each other, although there were differences because of different versions practiced. The Kyai invited the group to take a photograph together as a memento, but was respectfully rejected because it is not part of Sunnah. The next day, we had silaturrahmi to Pesantren of Syekh Muhammad Arsyad Al-Banjari under leadership of AlSyarwani Zuhri Al-Banjari in Balikpapan. This pesantren is one of the largest boarding schools in Samarinda with students numbering in hundreds. The Pesantren leaders are alumni of Madrasa Shaulatiyah of Mecca and Madrasa in Khadramaut Yaman. The dakwa of the Tablighi was welcomed by the kyai, even if they could not participate directly because of their busy schedule at the Pesantren. For two hours they were sharing experiences as a leader of Pesantren using Arabic.

During Khuruj, the entourage also visited hospitals and prisons. This program aims to promote hospital visit and pray for their dakwa in order to quickly recover from illness or die in a state of being a faithful Muslim. When I joined Khuruj for 3 days in the Mangku Palas mosque, Samarinda Seberang, I visited the Abdul Muis hospital. When we arrived, we asked for permission to visit the in-patients. We were divided into 2 groups and visited patients in different rooms. We introduced ourselves and prayed for the patients' recovery. A visit to the hospital was temporary according to local needs, not the teachings of the Tablighi center. The case in Samarinda, for example, the congregation was concerned with the dakwa movement in the Catholic hospital, where the pastor prays for dying Muslim patients. The followers of Tabligi worry that unconscious patients may be persuaded to abandon their faith by the clergy. Therefore, to fight the dakwa movement in this hospital, the Tablighi consistently visit the hospital. Another social program is visiting prison inmates for preaching. The presence of members of the Tablighi in the prison is quite interesting because not many preachers go directly to the correction center. The Tablighi see a big opportunity to preach in prisons. The entourage at the time visited prison class II A on Awang Long street, Samarinda. We were welcomed by prison officers and were provided an opportunity to meet 
and preach to the prisoners.

\section{“DEMAZHABIZATION" OF ISLAM: INTEGRATION OF THE OF LO- CAL AND GLOBAL SCHOOLS OF THOUGHT}

The emergence of the dakwa movement, the Tablighi, in the early 20th century in India has brought major changes to the development of Islamic dakwa movement. The Tablighi have been able to reach the rapidly growing number of 10 million followers in 180 countries The Tablighi's existence not only initiates a new approach to dakwa, but also emerges as an alternative movement that offers an alternative in the midst of tension and rigidity of the relation between Islamic mazhabs in which they are trapped in the war and prison of mazhab (school of thought) (George Abraham Maksidi, 2000). The phenomenon of mazhab has shackled the Muslims after the schools of thought became dogma and doctrine in the early 10th century. The results of the ijtihad were regarded as 'sacred' and 'taboo' to be criticized. Sincretization of mazhab is deemed as a deviation of religion, but mazhabs are not more than a product of ijtihad interpretation of the scholars of Islamic theology, law and politics. There are 8 schools recognized in Islam; Hanafi, Maliki, Shafi'i and Hanbali (Sunni) and Ja'fari, Ibadi and Zaidi (Shiite) (Charles Mwalimu, 2007). The problem is that each of the mazhab adherents believes that they are the most correct. This attitude is not only growing in the discourse, but also in social practices that lead to conflict and violence.

The phenomenon of prison of mazhab in the Islamic community has been a tradition, ingrained and difficult to remove. Differences of mazhab often lead to conflict and social violence, let alone ridden with political and economic interests such as Sunni and Shiite conflict (Iraq, Iran, Afghanistan, Syria, and Pakistan), and political conflicts of the Muslim Brotherhood (Egypt, Lebanon and Jordan). In Indonesia, the conflict between adherents of the mazhab is latent and continues to reproduce and escalate such as conflicts between NU and Muhammadiyah, NU and Wahabi, Ahmadiyah and FPI (Saipul Hamdi, 2014). The existence of mazhabs with differences of identity does not mutually reinforce each other, but rather mutually weakens each other.

I found the concept of 'demazhabization' developed by the Tablighi has given a new color in the construction harmonious social relations and also as an alternative to unite Muslims at a local and global level. There are two meanings contained in an effort of 'demazhabization', i.e, first, that the Tablighi does not recognize the existence of other mazhab. Secondly, the Tablighi acknowledge all mazhabs but should not be discussed and handed it to each congregation. The movement of 'demazhabization' can unite Muslims in the frame of a more 
universal and also free them from the mazhab prison because they prioritize individual freedom to choose schools of thought which fit them and do not force others to follow their mazhab. Attempts of 'demazhabization' are implemented in the teachings of the Tablighi that should not be touched, one of them talking about 'khilafiyah', let alone talking about their mazhab in front of other congregations (Maulana Muhammad Yusuf Alkandhalawi, 2008). When becoming a member of the Tablighi, the congregation must 'undress' their mazhab and receive the clothes that the other mazhab.

Plurality of mazhab and sects in Islam is a social reality that must be accepted gracefully and does not need to be questioned. Moreover, Prophet Muhammad had predicted a split in Islam in his Hadith as many as 73 groups (Saipul Hamdi, 2011). Muslims biggest homework now is how to manage and accommodate groups of mazhab in order to integrate and work together to promote dakwa of Islam. Poor management of mazhab has a major impact on social friction and conflict, especially the grassroots who do not understand the depth of the discourse and the origin of mazhab or known 'blind fanaticism'. Founder of the Tablighi was well aware of the major issues and offered a middle way to resolve it. There are four things that should not be touched in order to defend the Islamic Ummah, i.e. to discuss political issues both inside and outside the country, to discuss khilafiyah, to discuss the abominations of society, and to discuss the status and funding. To the Tablighi, discussing the differences of mazhab has no meaning, and simply divides the ummah, and leads to Islamic dakwa never reaching its full potential (Husen Usman Kambayang, 2009).

Sheikh Ilyas seeked to eliminate discourse 'khilafiyah' in the Tablighi by promoting basic teachings such as prayers, studying, respect for others, and preaching. The basic teachings of Islam are summed up in six properties i.e. the sentence of toyyibah (shahada), shalat khusu' wal 'khudu', ilmu ma'a dzikir, ikromul muslimin, tash-hihun niyyah, da'wah wat tabligh (Maulana Muhammad Yusuf Alkandhalawi, 2008). The toyyibah sentence 'asyhadu alla ilaha illallah' aims to bring confidence to the human heart and put faith only in Allah. This toyyibah sentence in the Tablighi's view is a sentence that is as strong as a unifier of human beings, especially the Muslims. When one says the toyyibah sentence, then no screen, hijab or the distance between them. This sentence can unite the whole tribes, nations, languages, classes, community organizations, mazhabs and classes in the frame of humanism and surrender to Allah.

The unification of the various mazhabs in the Tablighi is not as easy as it looks, in which each member must adapt to patterns of relationship and interaction of new and accepting differences without asking or questioning the members 
of other mazhabs. The adaptation process takes a long time because it has been an entrenched practice of debate and conflict discourse of mazhab. For example, when one member of the Tablighi of Mecca perform Khuruj at the headquarters of Al-Mubarok Samarinda performing the bayan, he is not aware of discussing the khilafiyah by issuing the view of Wahhabism and blames other teaching practices. This action lead to scolding by the local congregation who would ask him to stop the discussion of 'khilafiyah' as it is uncomfortable and may create conflict. The sensitive issue of mazhab differences among Muslims, including among the Tablighi, will only takes up energy to argue and justify each mazhab to be the most correct.

Negotiations of socio-religious space within the Tablighi are naturally and culturally constructed within the frame of brotherhood. The Tablighi emphasize 'ikromul muslimin', in honor of fellow Muslims by grounding the toyyibah sentence. Whenever they perform jaulah, congregations greet the public with toyyibah sentence. As did Sheikh Muhammad Taslim of Sri Lanka, when he met residents in Balikpapan he hugged and kissed his left cheek and right while smiling and saying the toyyibah sentence.

"Assalamua'alaikum, subhanallah we are brought together by Allah here. We are brothers and united with the toyyibah sentence "La ilaha illallah". We came all the way from Sri Lanka to preach and encourage fellow Muslims to establish the religion of Allah with the five daily prayers in congregation and listen to the bayan after sunset. Insha Allah, our meeting has been recorded by Allah and there will be later in heaven exactly what is happening today. Insh Allah together we pray in congregation after sunset, Insha Allah Insha Allah.

Granting freedom to all members of the Tablighi in the practice of mazhab and following local mazhab in the preaching gives a big advantage for the smooth dakwa process. The society, getting fed up with the conflict as a result of differences in the interpretation of mazhab, seems to find something new in the Tablighi. A phenomenon that arises is the strong currents of integration and interconnection between the 'local' and 'global' mazhab. Tabighi dakwa activities across the region and the country are part of the globalization and localization of Islam. Every week, month and year, the congregations visit each other (khuruj) alternately from one region or country to another. Meanwhile, I met with congregations from Saudi Arabia, Sri Lanka, Thailand, Bangladesh, and the congregation of Samarinda performed Khuruj to Malaysia, Japan, India, Thailand and Pakistan. In their dakwa, the Tablighi not only integrate the mazhab, but also the culture, traditions, and local and global languages. No stranger to the local congregation to hear the bayans in Urdu, Arabic, Sri Lankan, and English, but they remain focused'. 


\section{'DIVINITY' ECONOMY AND WIFE INDEPENDENCE IN THE TABLIGHI}

The Tablighi dakwa efforts through Khuruj fi sabilillah is the toughest program that generates a lot of controversy in the community. Khuruj requires confidence and sincerity to sacrifice much more not only time, labor, family, but also the economy. Khuruj requires considerable cost for transport and meals during the dakwa. Meanwhile each member must provide their own costs, including transportation and meals. The Tablighi do not have a sponsor and do not collaborate with any institution, including the government, so it is incorrect to say that the Tablighi dakwa is free. When there are members who help other members to bear travel costs, it is only in certain cases. However, senior members are so concerned about new members who want to go out for dakwa and usually they will provide a way out.

The accommodation during dakwa is not a problem because they sleep in mosques. They will move from one mosque to another. Congregations from abroad will receive free meal, all borne by the local congregation alternately. The provision of food for the congregations from abroad is because it has a lot of sacrifices that need to get help from another congregation. In contrast to the congregations who travel out of districts or provinces have to pay dues for meals between IDR 10,000-20,000 per day according to the results of deliberations. Khuruj is not only done once, but repeatedly and will have an impact on the existence and stability of the family's economy. Then the next question is the extent of Khuruj economic impact on the family and how the concept of economic development of families is constructed in the neighborhood the Tablighi?

Khuruj will not increase property or materially beneficial, but in reality it will reduce the wealth and family income because of decreased work productivity dramatically. The husband who was once so productive and had high obsession to collect money, after joining the spirit the Tablighi would change completely because they put religious matters above everything. Religion for the Tablighi is not a mere ritual, but the business fields that need to be worked out and disseminated sustainably so that people gain insight and spiritual transformation. One can imagine that members who perform Khuruj could come from the lower classes do not have enough resources to face economic hardship for themselves and their families left behind. I argue that Khuruj fi sabilillah has a major impact on the economic condition of the family of the Tablighi. Most members have experienced decreased financial income, some families even experienced economic crisis.

Several cases in the field interesting to see are among others how they negotiate 
the socio-economic conditions of their families with dakwa mission. Adnan, a member of the Tablighi congregation of Balikpapan explained that he did not have enough money to pay for his khuruj trip. He then borrowed money from his family in order to cover the costs and expenses of meals during Khuruj in East Java. As for the money left for the family at home was not enough so his wife had trouble, but he was confident that Allah will help them. Fortunately, the other congregations helped with the family's daily needs at home, such as rice, spending money, etc. Ihsan, a new member of the Tablighi Samarinda directly went out for dakwa leaving his business behind. His wife who was not ready to accept this condition was quite stressed out having to handle the business and taking care of the children. Ihsan's business was on the brink of collapse because it was not taken cared od properly. Akrom, a congregation from Sulawesi said that he had to sell household appliances for khuruj. His wife who was not ready to accept the fact, immediately attacked him. However, facing severe problems in the family did not stop Akrom from his struggle in path of Allah. After being left for 40 days doing dakwa outside Java, his wife survived and began to accept her husband's decision. Jumadil, a congregation from Lombok sold beef cattle to meet the costs Khuruj abroad. Another member, Rahman, mortgaged his rice field for dakwa abroad because he had no money for travel expenses. Of all these cases, it shows the principle that they were ready to sacrifice for Allah and what is sacrificed shall be rewarded multiplied in number. The Tablighi adhere to the verse 'if you help the religion of Allah, then Allah will help you'.

The belief that serves as the principle and ideology of those who are not worried about the economic conditions and surrender all matters of family life only to Allah is what I call "divinity economy". "Divinity economy" is an economic concept that centers on Allah. Although not all members of the Tablighi have the same view of 'divinity economiy', but most informants I interviewed held the concept of 'divinity economy' as their family's economic design. Extreme views in the economic concept of divinity contend that God will provide sustenance for them even though they have no job. They believe that Allah will give them an easier path and sufficient livelihood if they perform khuruj. Allah will ensure their families left behind during Khuruj will have good health, safety and economy. To the Tablighi, Allah is the source of everything, a source of pleasure, happiness, and property (Abdurrahman Ahmad AsSyirbuni, 2010). However, they do not negate the existence of the trials and challenges from Allah. The next question is whether the concept of 'divinity economy' is a form of escape from their inability to seek sustenance or even a solution to the economic crisis by the Tablighi family when perfoming khuruj. 
In the teachings of Sufi, attitude that does not care about the worldly material is called the 'zuhud' (Rofiatul Ulya, 2003). Humans do not have the strength to resist or refuse the provision of the will and power of Allah. Allah will lift anyone he wants and let fall whom he wills. From this concept the Tablighi gave their life totally to the religion and sacrifice in the path of Allah. Despite the fact that there are some who have to sell his property for khuruj, and some who borrow from the family, it is all considered a path or the trials of life that must be faced. They believe the more they go out for dakwa, the easier the matters with material or worldly affairs. The concept of 'Divinity economy' has been ingrained in most members of the Tablighi doctrine and is difficult to change.

To minimize the economic issues at the level of families left behind during dakwa, the Tablighi create a program called 'nusroh'. Nusroh comes from the word nasharo meaning 'to help', in this context helping people abandoned by their families. Nushroh pattern is modeled on the Prophet's dakwa that divided the role of Muslims as the Ansor (helper) and as muhajirin (khorij). Each member of the family left behind during Khuruj will be a shared responsibility for the Tablighi members in their area to provide assistance. Each week alternately congregations who do not go out will visit families to help their needs. Usually congregations bring rice, money and other food to provide for the family left during Khuruj. Nushroh program can be a quick solution to help families economically strapped because of being left for khuruj.

New perspectives established by the Tablighi in conjunction with Khuruj is to straighten faith of the community that has not recognized or deviate from the teachings of Islam. The growing belief in the community is that property and other needs come from a husband, not Allah. This indirectly affects the excessive dependence of the wife on the husband, and not on Allah. This deviation to the Tablighi can only be changed through khuruj, where the wife left during Khuruj must be trained independently and should be capable of running her own life with her children at home without being accompanied by her husband. The wife is required to adapt to her husband's new life by removing dependence on him. They take care of their own children to school, keep the farm, earn money and are responsible for everything during her husband's khuruj.

\section{CONFLICT NARRATIVES OF THE TABLIGHI FOLLOWERS}

In addition to bringing peace in their message, the Tablighi also bring conflict and discord in the family and society. This is a consequence of the mission of dakwa movement brought to the middle of a family tradition and a pluralistic 
society of multi-culture. In the internal family, for example, conflicts between husband and wife is nolonger a public secret when a husband joins the Tablighi, without telling his wife in advance. Total changes shown by the husband after joining the Tablighi usually shocks his wife. The wife has to adjust and change the pattern of her life to compensate for the new lifestyle of her husband who is more focused on religion. A wife who understands will usually be happy to see the change in her husband who has received guidance to learn religion. The husband who used to worship less, after joining the Tablighi, worship more often and have stronger faith. This is the figure of an ideal husband a wife is expected to have to guide them to the straight path.

This subsection will focus on the narratives of conflict and social friction that occur in the family and society. Diverse narratives appear related to the conflict they face. Rahmat, one of the members of the Tablighi said that it had been nearly three years since he was dumped by her wife's family for joining the Tablighi. Since joining the Tablighi, he showed a change in attitude, and he was expelled by his in-laws out of his home and had to sleep in the mosque with the a few pieces of clothes. The resistance of the wife and the family could be stopped as the change in Rahmat's attitude that no longer cared about his family. Since joining the Tablighi, he had to change his appearance from clothing (wearing gamis), way of eating, taking care of the body, growing beard to imitate the Sunnah of the Prophet. Despite resistance and protest, Rahmat believed that his wife and family had not received guidance from Allah so it was normal that they resisted him. He believed if his wife had received guidance then her behavior would change. They will accept a new lifestyle and join him later. His wife did not dare to sleep alone because she was not accustomed to. For three years, the household never got along and almost broke up, slowly she regained consciousness and began to accept his dakwa activities. Another narration of Imron, who burned his wife's clothes because they looked 'sexy' and exposed private parts. He did this after entering the Tablighi and thought of his wife's behavior being the behavior of the devil that is not in accordance with the teachings of the religion of Allah. He started from the change in himself, then his family in order to revolutionize their mentality. He began to fix the clothes, the nature and character of his wife that violate the rules of Islam. Seeing the change in the attitude of the husband, his wife immediately responded that she could not accept her husband's actions. She was screaming, rolling on the streets and depressed, while he tried to hold back and not too bothered by his wife's action because in his view she was possessed by Satan. This event caused the people in the village shocked and wondered why his wife suddenly acted like that. Imron let these things happen and still went out for Khuruj fi sabilillah with confidence that Allah will change the attitude and behavior of 
his wife at any time if she gets guidance. He believes all of this is a result of not opening the door of Allah's guidance. After four months of dakwa in East Java without giving news to his wife, someone called him and said that his wife had worn a hijab. He could not believe it how she could change drastically, while he had not preached on her. However he was convinced that his prayers were answered by Allah. Not long after that he got news that she started to wear a purdah. He saw this phenomenon as a miracle, all of this could not be forced and all arranged by Allah. The dakwa activities of Imron are getting easier because his wife began to support him. Once returning home to his wife, the intensity of 'makomi' dakwa performed by Imron further strengthened his wife's belief to join the Tablighi. They are both now very active and often go out for dakwa (masthuroh).

Another narrative concerns the family of Ahmad as his wife asked for a divorce if he continued the dakwa in the Tablighi. His wife was very depressed to see the changes in his behavior that was no longer concerned with the employment and education of children. Her husband was only concerned with dakwa. During her husband's Khuruj, she had to handle all her husband's duties and responsibilities including taking care of business and taking the children to school. She gave an ultimatum to the husband to quit the Tablighi or to have a divorce. Another story that emerged was a fight between husband and wife because the husband sold their assets for dakwa needs. Zainudin, another member of the Tablighi who originated from Lombok mortgaged his land to preach abroad. His wife could not bear the economic pressure, so divorce was the only way out for this couple.

Abu Nizom had a different experience where all his family opposed and pressed him against going out for dakwa. He planned to perform Khuruj for 10 days as scheduled, but had to accept the fact that at the time his wife was sick and the tobacco harvest from his farm had not been completed. His decision to go out for dakwa had caused his parents to be angry as his wife was sick and the tobacco harvest neglected. His father then went out to find Abu Nizom and found him in a mosque. He challenged his son to fight if he insisted on continuing with the dakwa. Seeing his father's attitude, Abu Nizom could only asked for forgiveness from Allah. Finally he relented and returned home to leave the arena of dakwa. He did not have much choice because of family pressures that forced him to return home.

External conflicts with the public are also a major problem faced by the Tablighi. Conflicts arise when they are dealing with people who do not understand the religious culture of the Tablighi. The story of the rejection of the presence of the Tablighi in mosques is a common story that happens everywhere. Local 
communities reject the use of mosques in their area as a center of the Tablighi dakwa activities as it is deemed to 'contaminate' the mosque. To carry out the mission of dakwa, the Tablighi not only make the mosque as a place of worship, but also as a place to stay for dakwa. They sleep, wash, cook and eat in the mosque. Local people worry that sleeping in the mosque will have an impact on the cleanliness of the mosque, and could then cancel the validity of prayer as their saliva may fall on the praying mat. Although the Tablighi always keep clean, not all can accept their presence.

Cooking in the mosque with a stove gives an impression of the mosque being used as a 'religious camping. Likewise, eating in the mosque is considered less suitable. People who are not accustomed to seeing this scene may feel uncomfortable. In addition, washing and drying clothes make the atmosphere of the mosque unpleasant to look at. The issue whether to accept or reject the Tablighi who wish to deliver Khuruj in their mosque is quite dilemmatic. In Samarinda, some mosques shut down their door to the Tablighi movement, including the grand mosque and Islamic Center of Samarinda which serve the center of social and religious activities of Muslims in East Kalimantan. The mosques belonging to certain organizations such as Muhammadiyah mosque and Salafi mosque also firmly reject the Tablighi.

The Jaulah method of dakwa of the Tablighi by knocking at the doors of homes also became a hot issue in the community. Some residents on Jl. Suryanata Samarinda for example, close the door of their home when the Tablighi come to preach on them. They feel that there is coercion and interference with the free exercise of religious worship practices. They are also considered to interfere with the stability of the activities of citizens as the group members suddenly come to preach. The Tablighi were attacked by the villagers when they performed Khuruj in an area in East Java. A group of residents were not happy with their mission as it was seen to disturb the tranquility of citizens. They were besieged inside the mosque and intimidated, but because of the help of Allah they survived. They relented and were immediately evacuated from the mosque.

The bombing case that occurred in the tourist island of Bali in 2002 directly had an impact on the Tablighi. Some residents claimed that they were part of a terrorist movement because of their clothes and appearance that look like a terrorist. The Tablighi followers had difficulties to go abroad for dakwa. They were intercepted and interrogated intensely at each airport. Their passports were confiscated and not allowed to continue flying abroad. This accusation was exaggerated because not everyone involved wearing big clothes and growing beard are terrorists. The Tablighi members just fall victim to local politics after 
the attacks in Bali in 2002 and 2005 that killed tourists from foreign countries. The Tablighi tried hard to recover the image and accusations directed to them through the teachings of anti political campaign and just focusing on religious dakwa.

Conflicts between the Tablighi and the Wahabi also occurred in several regions in Indonesia, including Samarinda. The Wahhabis accused the Tablighi of doing bid'ah. The Khuruj pattern with a certain period of time, such as 3 days, 10 days, 40 days and 4 months, in the views of the Wahhabis, has no basis in the Quran and Hadith. Abu Mussab Wajdi Akkari, Wahhabi figure in his speech said that the pattern of dakwa of the Tablighi has been categorized as heresy, even the Tablighi has become a new religion because members must follow with urgent situations. The Wahhabis also view the Tablighi as not having adequate intellectual culture because they negates the discussion of mazhab and theology. Science and religious discourse of the Tablighi are shallow as it approaches the anti mazhab. The Tablighi also claimed to not follow the practice of companions of the Prophet and misunderstood the motion dakwa. Akkari also regarded the Tablighi as not appreciating the differences, and their kindness is gone when they disagree with other groups.

Sheikh Assim Al Hakim, a Wahhabi cleric claimed that the Tablighi had no clear reference when performing Khuruj fi sabilillah. They are considered heretical because they created their own practice of worship not based on the Quran and Hadith. "The book they use among others, Fadoilul Amal, is less qualified because many hadiths quoted are invalid," said Al-Hakim. This piece of works is not comparable to the previous works of the imams. This debate has triggered a lot conflicts with the Wahhabis who always attacked them with regard to the religious basis used. The Tablighi are also considered deviant because they do not care about their families and too busy doing dakwa outside their neighborhood, while the congregation around them are not involeved in their dakwa.

\section{CONCLUSION}

The Tablighi play an important role in the dakwa movement at the local and global level as a middle path in the midst of the cold social relations between Muslim groups because they are stuck in the mazhab debate. Muslims split due to differences in mazhab, sects and ideological differences in the organizations, sometimes even ending up with conflict and social violence. In addition, a conflict of mazhab is intervened with political and economic interests which will certainly add to the complexity of the problems. The Tablighi's constructive efforts of 'demazhabization' of Islam by taking the religion away from the 
context of the debate is a breakthrough of solution. The Tablighi do not look at the background of mazhab, sects or ideology of their members, but on the contrary, they accommodate and integrate them into a universal movement. The Tablighi opened the door wide and seek to bring together all the elements of Muslims to join in their dakwa movement. The Tablighi at times act as a large umbrella for groups that are members of community organizations or institutions that participate in their mission.

The Tablighi are not part of the Salafi or Wahabi which has been widely claimed by the community. The Tablighi also are not mass organizations, institutions, or organizations but an embryo of the dakwa movement which is a modification of the various thareqats namely Al-Jistiyah, Naqsabandiyah, Qadariyah dan As-Sahrowardiyah. The four thareqats have been developed, reconstructed and reformed to be Thareqat Nabawi which emphasizes on dakwa. According to Sheikh Ilyas, thareqat is meaningless if it only brightens the individual spirituality, while the other Muslim societies are still in the dark. Therefore, the only way is to preach to the society. The Tablighi through Thareqat Nabawi focus on dakwa activities at home and abroad. They positioned the religion as an endeavor and dakwa as an activity that need to be done continuously. Dakwa is one of the activities of Prophet Muhammad and his companions who never stopped preaching and at any time and any place.

Full concentration on religious dakwa programs such as Khuruj fi sabilillah has given birth to the concept of 'Divinity economy' within the Tablighi. Although they use only $10 \%$ for the activities for dakwa (3/month, $40 /$ year and $4 /$ lifetime), but the impact is huge on the existence of economic families where the Tablighi are no longer productive in finding sustenance and submit economic matter entirely to Allah. The Tablighi are not so concerned with the family's economy because they are sure that Allah will guarantee and give sustenance to those who fought in His path. Worldly obsession to the Tablighi is a disease that must be removed and transformed into the obsession of the hereafter. The world is only temporary and does not need to be glorified, in contrast to the Hereafter is lasting and tangible. If the intention of the struggle and dakwa has been made, money and one's own family's needs will come from Allah. Allah will send help through other people. This Tablighi argument serves the basis for me to coin the term 'Divinity economy' in the Tablighi ideology that only relies on Allah's power.

The Tablighi dakwa is a mission of peace and unification of Muslims. However, in reality, they face a variety of conflicts both in the family and community. Most families of those who joined the Tablighi had difficulties due to economic problems and the principle of family life that had to adapt to the pattern of 
the Tablighi dakwa. Family economic crisis cannot be avoided in the family institution as the Tablighi do not have an obsession to pursue the world, while the needs of their own families and the needs of dakwa are quite demanding. They have to spend money on transportation costs and meals for dakwa outside the region and abroad. The dakwa needs are quite demanding for the Tablighi, let alone providing for the family. Unlike the Tablighi members who are richer, they are not difficult to cover the family's needs. The nushroh program is one solution to overcome economic hardship of families during the trip, where ther members who are not doing dakwa will help them. However, nushroh is only temporary because after khuruj a husband must think of his family's economic life.

In addition to family conflicts, the Tablighi also face a conflict with the community which becomes the object of their mission. People feel uncomfortable with the pattern of dakwa of the Tablighi where they knock at the doors of their homes because it is regarded as coercion and intervention in the private area. Residents also do not want them use the mosque as a place to stay for dakwa because it can contaminate and disrupt the residents' worship activities. Islamic organizations, especially the Wahhabis, are very keen on preaching that the Tablighi are misguided because they have created new rules of worship that did not exist in the days of the Prophet. Provisions of time in dakwa never existed in the days of the Prophet, if you have the opportunity to preach anywhere and anytime. These conflicts for the Tablighi only a trial from Allah that must be faced. the Tablighi sure that this problem occurs as people have not blessed with guidance from Allah.

\section{REFERENCES}

Ariesta, 2009. Alasan-alasan Bertahannya Masyarakat Ekonomi Kelas Bawah dalam Keanggotaan Jamaah Tabligh (Studi di Nagari Ampang Kuranji Kecamata Kota Baru Dharmasraya), Skripsi Universitas Andalas.

As-Syirbuny, 2010. Abdurrahman Ahmad, Kupas Tuntas Jamaah Tabligh 1, Jakarta: Pustaka Nabawi.

BPS Samarinda, 2014. Samarinda dalam Angka 2014, Samarinda: BPS.

BPS Samarinda, 2013. Samarinda dalam Angka 2013, Samarinda: BPS.

Deliso, Christopher. 2007. The Coming Balkan Caliphate: The Threat of Radical Islam to Europe and the West, Westport: An Imprint of Greenwood Publishing Group.

Fikri, Rivai. 2010. Aktivitas Dakwah Kyai Najib Al-Ayyubi, Skripsi UIN Syarif Hidayatullah. 
Hamdi, Saipul. 2014. Nahdlatul Wathan di Era Reformasi: Agama, Konflik Komunal dan Peta Rekonsiliasi, Yogyakarta: KKS.

2011. "Ahmadiyah di Era Reformasi," in Jurnal Al-Ulum, Vol. (11), 1: $27-46$.

Hedges, Joshua W. 2008. Tablighi Jamat: The Premier Laten Network. The Fund for Peace: Reseacrh Report.

Janson, Marloes, Islam, Youth and Modernity in the Gambia: The Tablighi Jama'at, New York: Cambridge University Press, 2014.

Kambayang, Husen Usman. 2009. Usaha Da’wah \& Tabligh: Terapi Rohani Paling Menakjubkan, Bandung: Pustaka Ramadhan.

Maksidi, George Abraham. 2000. Cita Humanisme Islam: Panorama Kebangkitan Intelektual dan Budaya Islam dan Pengaruhnya terhadap Renaisanse Barat, (translated from The Raise of Humanism and in Classical Islam and the Christian West oleh A. Syamsu Rizah \& Nur Hidayah). Jakarta: PT. Serambi Ilmu Semesta.

Mwalimu, Charles. 2007. The Nigerian Legal System: Public Law, Volume 1, New York: Peter Lang Publishing.

Noor, Faris A. 2012. Islam on The Move: The Tablighi Jamaat in Shout East Asia, Amsterdam: Amsterdam University Press.

Rana, Muhammad Amira. 2009. Tablighi Jamaat: The Discourse and Challenge, Pakistan: Pak Institute for Peace.

Sikand, Yoginder. 2007. “The Reformist Sufism of the Tablighi Jamaat: The Case of the Meos of Mewat, India," in Martin Van Bruinessen and Julia Howell, Sufism and the 'Modern' in Islam, London: I.B.Tauris \& Co Ltd.

Sholikhin, Muhammad. 2009. 17 Jalan Mencapai Mahkota Sufi: Syaikh Abdul Qodir Al-Jaelani, Yogyakarta: Mutiara Media.

Tim Ahlul Bait Indonesia, Hitam Putih Mazhab Syiah Menurut Para Ulamanya yang Muktabar, Jakarta: DPPABI, 2012.

Ulya, Rofiatul. 2003. Zuhud dari Zaman ke Zaman, Mini theisis at Fakultas Ushuluddin UIN Sunan Kalijaga.

Yusuf, Maulana Muhammad. 2008. Muzakarah Enam Sifat Para Sahabat \& Amalan Nurani, Bandung: Pustaka Ramadhan.

Zakariyya, Maulana Muhammad. 2003. Fadhoilul A'mal (translated by Abdurrahman Ahmad). Yogyakarta: Ash-Shaff.

\section{Internet:}

Https://nexlaip.wordpress.com/2012/08/15/pendapat-ulama-seputar-jamaah-tabligh/ di download 02 April 2015.

Http://www.samarindakota.go.id/content/sejarah-kota-samarinda, 02 April 
2015.

Http://bappeda.samarindakota.go.id/profil_01.php, 02 April 2015.

Https://kautsaramru.wordpress.com/2013/02/17/apakah-jamaah-tabligh-bermanhaj-tasawuf/, 02 April 2015.

Https://tetesanhujan.wordpress.com/2008/11/17/apakah-khuruj-3-hari-40hari-dan-4-bulan-itu-bidah-bag-1/, 03 April 2015. 